\title{
Pemberdayaan UMKM Berbasis "One Village One Product (OVOP)" Sebagai Gerakan Ekonomi Kerakyatan Pada Industri Logam di Desa Hadipolo Kudus
}

\author{
Ita Rakhmawati \\ IAIN Kudus \\ rakhmaita@gmail.com
}

\begin{abstract}
One Village One Product (OVOP) is one of the programs initiated by the government in order to improve rural welfare and equality through empowering MSMEs. The purpose of this study was to see the effectiveness of the development of OVOP in the metal industry MSMEs in the Hadipolo, Jekulo Kudus. This research is a type of field research with a qualitative descriptive approach. The technique of collecting data through interviews, observation and documentation. The data analysis technique starts from reducing data to concluding. The parameters of OVOP-based empowerment analysis include objectives, initiators, parties involved, sources of funding, implementation stage, form of participation in determining products, designs, forms of assistance and marketing channels. The results of the study show that all of these parameters have been running but have not reached the maximum, efforts need to be made to improve.
\end{abstract}

Keywords: MSMEs Empowering, One Village One Product (OVOP), People's Economy

\begin{abstract}
Abstrak
One Village One Product (OVOP) adalah salah satu program yang diprakarsai oleh pemerintah dalam rangka meningkatkan kesejahteraan pedesaan dan kesetaraan melalui pemberdayaan UMKM. Tujuan dari penelitian ini adalah untuk melihat efektivitas pengembangan OVOP pada UMKM industri Logam Desa Hadipolo Kudus. Penelitian ini merupakan jenis penelitian lapangan dengan pendekatan deskriptif kualitatif. Teknik pengumpulan data melalui wawancara, observasi dan dokumentasi. Teknik analisis data dimulai dari mengurangi data hingga menyimpulkan. Parameter analisis pemberdayaan berbasis OVOP meliputi tujuan, pemrakarsa, pihak yang terlibat, sumber pendanaan, tahap implementasi, bentuk partisipasi dalam menentukan produk, desain, bentuk bantuan, dan saluran pemasaran. Hasil penelitian menunjukkan bahwa semua parameter ini telah berjalan tetapi belum mencapai maksimum, upaya perlu dilakukan untuk meningkatkan.
\end{abstract}

Kata kunci: Pemberdayaan UMKM, One Village One Product (OVOP), Ekonomi Kerakyatan

\section{PENDAHULUAN}

Globalisasi membawa dampak besar bagi perekonomian dalam negeri, salah satunya adalah dominasinya produk asing di pasar dalam negeri dengan harga yang kompetitif. Berbagai produk mulai dari makanan, fashion, farmasi, elektronik dan juga produk rumah tangga dari berbagai negara membanjiri pasar lokal. Hal ini tidak hanya terjadi pada pasar tradisonal saja bahkan juga pada sistem perdagangan digital (e-commerce). Bibli, salah satu 
situs dagang di Indonesia mengakui bahwa dari 2,5 juta produk yang dijual namun hanya 50.000 sampai dengan 100.000 produk yang merupakan produk local (https://www.merdeka.com/uang/dikuasai-produk-asingmendag-wajibkan-e-commerce-jual-produk-lokal.html). Hal ini berarti $98 \%$ dari produk yang dijual merupakan produk asing sedangkan produk lokal hanya pada kisaran angaka 2\%. Bahkan pasca penandatanganan Perjanjian ASEAN Forum Trade Aggrement - Cina pada Januari 2010, membuka kran besar bagi masuknya produk China terutama elektronik ke Indonesia. Hal ini jelas memberikan tantangan yang lebih besar terhadap daya saing produk dalam negeri baik di pasar nasional bahkan internasional.

Hal tersebut diperparah lagi dimana kecenderungan masyarakat Indonesia yang lebih banyak bersifat konsumtif dibandingkan produktif. Hampir setiap produk asing dari berbagai negara dengan berbagai merk laris manis dijual di Indonesia bak kacang godog di musim penghujan. Kurangnya kesadaran masyarakat untuk menggunakan produk lokal serta dampak yang ditimbulkan turut memperparah kondisi tersebut. Gaya hidup masyarakat yang lebih banyak memperhatikan aspek prestice dan gengsi turut meningkatkan potensi konsumsi produk asing. Akankan kondisi demikian dibiarkan secara terus menerus? Akan seperti apakah kondisi perekonomian dan industri dalam negeri jika hal tersebut terus berlangsung? Tentunya dampak buruk berupa gulung tikarnya industri dalam negeri, meningkatnya jumlah pengangguran serta defisitnya neraca perdagangan Indonesia akan berada di depan mata.

Kondisi demikian tidak dapat dibiarkan secara terus menerus. Upaya penyelamatan ekonomi nasional disektor perdagangan dan industri perlu dilakukan segera mungkin. Salah satu upaya yang harus segera dilakukan adalah perlunya penguatan pasar domestik terutama yang berbasis pada potensi daerah. Mengapa hal ini perlu dilakukan? Indonesia sebagai negara yang prural memiliki banyak keanekaragaman dan potensi baik sumber daya alam maupun sumber daya manusia. Potensi inilah yang perlu dikembangkan agar demokrasi ekonomi yang diamanahkan oleh UUD 1945 terutama dipasal 33 dapat direalisasikan. Demokrasi ekonomi Pancasila yang mana perekonomian bersumber dari rakyat, oleh rakyat dan untuk rakyat.

UMKM meruapakan salah satu badan usaha yang menjiwai falsafah demokrasi ekonomi pancasila. UMKM banyak didirikan dari masyakat, dikelola oleh masyarakat dan hasilnya dinikmati oleh masyarakat. Keberadaan UMKM memiliki peran penting dalam perekonomian antara lain mampu menyerap tenaga kerja sehingga dapat mengurangi pengangguran, meningkatkan pendapatan nasional serta memacu pertumbuhan ekonomi daerah. UMKM sebagai pelaku utama industri yang berbasis potensi daerah perlu dirangsang pertumbuhannya agar mampu menghasilkan produk yang berstandart internasional, sehingga harapan produk dalam negeri dapat menjadi tuan rumah di negaranya sendiri bahkan menjadi tamu istimewa diluar negeri bisa terealisasi. 
Pemberdayaan UMKM berbasis "One Village One Product" (OVOP) Sebagai Gerakan Ekonomi Kerakyatan Pada Industri Logam Desa Hadipolo Kudus

UMKM merupakan sektor usaha yang paling banyak memberikan kontribusi terhadap perekonomian di Indonesia. Data BAPPENAS menunjukkan Jumlah UMKM pada tahun 2015 mencapai 60,7 juta unit dan yang berskala mikro sebesar 98,7\%. Keberadaan UMKM mampu menyerap tenaga kerja sebanyak 132,3 juta tenaga kerja. Sedangkan kontribusi UMKM pada pembentukan PDB tahun 2009 - 2013 mencapai 57,6\%. Potensi UMKM yang sedemikian besar ternyata belum mampu mengimbangi persoalan rendahnya daya saing produk lokal baik di tingkat nasional dan juga internasional.

Kenyataan yang terjadi di lapangan menunjukkan UMKM mengalami berbagai persoalan sehingga sulit berkembang. Permasalah tersebut mulai dari minimnya inovasi baik dalam produk maupun proses, standarisasi produk yang rendah, terbatasnya jangkauan pemasaran, keterbatasan modal dan minimnya jaringan kemitraan keluar. Salah satu upaya dalam rangka memberdayakan UMKM adalah melalui pemberdayaan berbasis One Village One Product.

Pemberdayaan UMKM berbasis One Village One Product adalah upaya bersama baik dari pihak UMKM, pemerintah, masyarakat dan seluruh stakeholder dalam rangka meningkatkan added value serta kemandirian UMKM dengan mendasarkan pada potensi khas daerah yang dimiliki. Hal ini bukan hanya semata dalam rangka kepentingan ekonomi tetapi juga mampu mendorong kesetaraan antara pedesaaan dan perkotaan. Dengan demikian program tersebut diharapkan mampu meminimalisasi gap antar desa dan kota. Sehingga berbagai persoalan sosial yang sering terjadi seperti urbanisasi, pengangguran, kemiskinan dan pertumbuhan ekonomi yang lambat dapat terurai.

Penelitian Triharini (2012: 28-41) yang berjudul Pendekatan One Village One Product untuk Mengembangkan Potensi Kerajinan Gerabah di Kecamatan Plered Purwarkarta menyatakan bahwa hal tersebut tidak hanya memberikan manfaat secara ekonomi berupa peningkatan pendapatan keluarga pengrajin tetapi juga mampu menjaga kearifan lokal melalui nilai nilai tradisonal yang diwariskan kepada generasi muda. Kemudian untuk aspek aspek OVOP untuk setiap cluster UMKM memiliki keunikan tersendiri yang berbeda dengan cluster UMKM lainnya. Pelaksanaan program OVOP di daerah Plered masih belum maksimal sesuai dengan prinsip yang dikembangkan. Perlu adanya dukungan dan keterlibatan seluruh stakeholder guna mendukung keberhasilannya. Sedangkan penelitian tentang Pendekatan One Village One Product untuk Meningkatkan Kreatifitas UMKM dan Kesejahteraan Masyarakat yang dilakukan oleh Rusnandari (2013) menghasilkan bahwa terdapat beberapa hambatan dalam mengembangkan OVOP di Surakarta antara lain lemahnya koordinasi antar stakeholder, kurangnya kesadaran masyarakat akan potensi ekonomi di daerahnya serta kurangnya dukungan dana pemerintah pusat dan pemerintah daerah. Namun disatu sisi pengembangan OVOP di kawasan batik Surakarta cukup signifikan 
dengan telah terbentuknya koperasi simpan pinjam yang membantu UMKM disektor permodalan.

Kudus merupakan kota kecil di wilayah utara Jawa Tengah yang terkenal slogannya Gusjigang (Bagus, Ngaji dan Dagang). Hal ini bukan hanya sekedar slogan semata, Keberadaan sektor perdagangan sebagai salah satu tumpuan ekonomi benar benar terbukti keberadaannya. Bukan hanya sektor ritel dan perdagangan besar, justru keberdaan UMKM lah yang berpotensi besar menggerakkan perekonomian daerah. Berdasarkan data yang diperoleh secara langsung dari Dinas Tenaga Kerja, Perindustrian, Koperasi dan UMKM, jumlah pelaku UMKM di Kudus diperkirakan mencapai 12.000 UMKM yang tersebar di sembilan kecamatan.

Desa Hadipolo yang lebih terkenal dengan sebutan bareng merupakan salah satu desa di kecamatan Jekulo yang di kenal sebagai desa Sentra Pande Besi. Terdapat banyak UMKM pande besi yang sudah berdiri sejak berpuluh puluh tahun yang lalu. Produk yang dihasilkan adalah alat alat pertukangan dan pertanian yang berasal dari industri logam seperti pisau, cangkul, golok, sabit, cetok, garu dan lainnya. Namun, potensi dan kearifan lokal ini sayangnya lambat laun mulai tergerus oleh zaman hal ini ditandai dengan semakin berkurangnya pelaku UMKM pande besi di daerah tersebut. Berbagai persoalan yang sering dihadapi oleh wirausahawan salah satunya adalah minimnya sektor permodalan karena terbatasnya UMKM terhadap akses kredit usaha rakyat dari perbankan. Minimnya inovasi dan standarisasi produk memberikan dampak daya saing produk yang kurang kompetitif. Pada sektor pemasaran, proses pengemasan dan segementasi pasar menjadi hambatan bagi para wirausahawan.

Pada satu sisi industri logam yang menghasilkan berbagai peralatan rumah tangga ini merupakan industri potensial khas daerah setempat. Untuk kawasan Kudus, hadipolo merupakan satu satunya sentra industri pande besi yang ada. Diakui oleh salah satu pengrajin, bahwa sebenarnya potensi permintaan dan kebutuhan alat alat rumah tangga seperti pisau, sabit dan juga perlatan dapur dari berbagai kota dan propinsi sebenarnya masih besar. Kebutuhan terhadap bahan baku mendapatkan suplai yang cukup besar dari keberadaan pengepul besi mati yang banyak terdapat di desa tersebut.

Berdasarkan pada fakta fakta diatas, maka penulis tertarik untuk mengetahui lebih lanjut dan meneliti tentang "Pemberdayaan UMKM Berbasis One Village One Product (OVOP) sebagai gerakan ekonomi kerakyatan Pada Industri Logam Desa Hadipolo Kecamatan Jekulo Kabupaten Kudus"

\section{KAJIAN LITERATUR}

Pendekatan One Village One Product pertama kali dicetuskan oleh Prof. Morihiko Hiramatsu seorang gubernur Oita di Jepang pada tahun 1980 (Egypt Network For Integrated Development). Konsep ini selanjutnya diadopsi oleh negara - negara di Asia termasuk Indonesia. Menurut Peraturan Menteri perindustrian No 78 Tahun 2007 menjelaskan bahwa Satu Desa 
Pemberdayaan UMKM berbasis "One Village One Product" (OVOP) Sebagai Gerakan Ekonomi Kerakyatan Pada Industri Logam Desa Hadipolo Kudus

Satu Produk (OVOP) adalah salah satu pendekatan pengembangan potensi daerah di satu wilayah untuk menghasilkan satu produk kelas global yang unik, khas daerah dengan memanfaatkan sumber daya lokal.

Pengembangan OVOP dilaksanakan dengan mendasarkan pada tiga prinsip utama yang saling terkait, seperti pada bagan berikut:

Bagan 1.

Prinsip OVOP

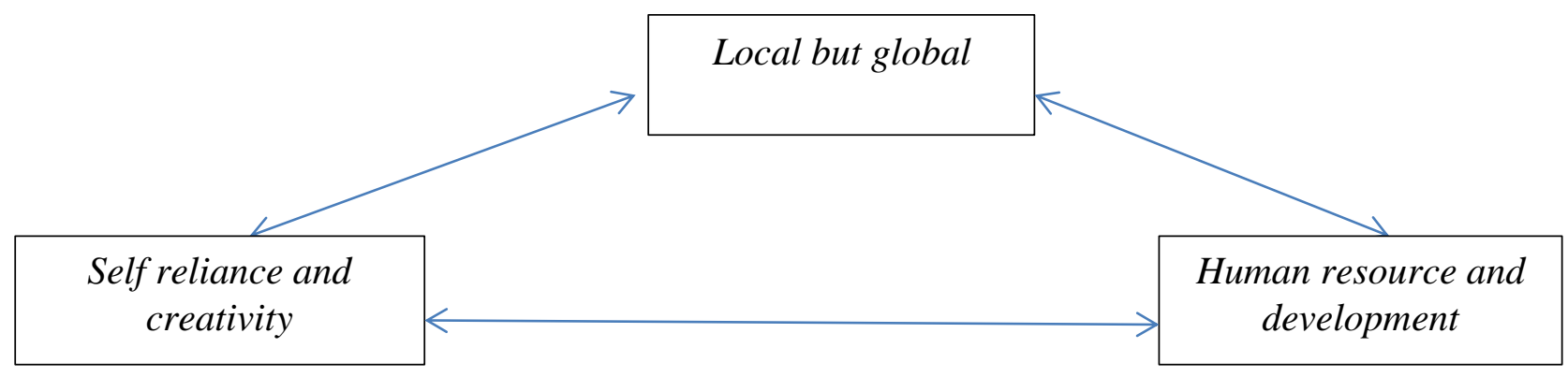

1. Prinsip local but global merupakan prinsip yang berarti UMKM di desa dengan mengoptimalkan potensi lokal yang dimiliki namun menghasilkan produk dengan kualitas dan mampu diterima secara global

2. Prinsip Self reliance and creativity merupakan prinsip yang berarti dalam pengembangan potensi desa harus berdasarkan kemandirian, inisiatif dan kraetifitas masyarakat setempat

3. Prinsip Human resource and development merupakan prinsip yang berarti program OVOP harus mampu mengembangkan sumber daya manusia yang ada agar lebih kreatif dan mandiri

Dalam petunjuk teknis pelaksanaan dan pengembangan IKM melalui pendekatan OVOP yang dikeluarkan oleh Kementrian Perindustrian terdapat persyaratan produk yang harus dipenuhi, meliputi kategori produk, persyaratan produk, persyaratan IKM dan jumlah contoh produk. Kategori produk yang dapat masuk sebagai seleksi OVOP dapat berupa makanan, minuman, kain tenun, kain batik, anyaman dan gerabah. Persyaratan umum yang harus dimiliki oleh produk harus memiliki keunikan / kearifan tunggal, berpotensi dieksport serta proses produksi berlangsung secara kontinyu. Sedangkan bagi pengrajin atau pelaku IKM nya harus memiliki legalitas usaha baik berupa TDI (tanda daftar Industri) atau IUI (izin usaha industri).

Menurut Peraturan Menteri Perindustrian No 78 tahun 2007 Strategi pengembangan UMKM dengan pendekatan OVOP dapat dilakukan antara lain:

1. Kolaborasi antara pemerintah pusat, pemerintah daerah, sektor swasta dan masyarakat lokal

2. Pemanfaatan pengetahuan, tenaga kerja dan sumber daya lokal lainnya yang memiliki keunikan khas daerah

3. Perbaikan mutu dan penampilan produk

4. Promosi dan pemasaran pada tingkat nasional dan global. 
Menurut UU No. 20 tahun 2008, Usaha Mikro adalah usaha produktif milik orang perorangan dan/atau badan usaha perorangan yang memiliki kekayaan bersih maksimal Rp. 50.000.000,00 dengan hasil penjualan tahunan maksimal Rp. 300.000.000,00.

Sedangkan yang disebut dengan Usaha Kecil adalah usaha ekonomi produktif yang berdiri sendiri, yang dilakukan oleh orang perorangan atau badan usaha yang bukan merupakan anak perusahaan atau bukan cabang perusahaan yang dimiliki, dikuasai, atau menjadi bagian baik langsung maupun tidak langsung dari usaha menengah atau usaha besar yang memiliki kekayaan Rp. 50.000.000,00 sampai dengan Rp. 500.000.000,00, serta memiliki hasil penjualan tahunan antara Rp. 300.000.000,00 samapai dengan Rp. 2.500.000.000,00.

Usaha Menengah adalah usaha ekonomi produktif yang berdiri sendiri, yang dilakukan oleh orang perorangan atau badan usaha yang bukan merupakan anak perusahaan atau cabang perusahaan yang dimiliki, dikuasai, atau menjadi bagian baik langsung maupun tidak langsung dengan usaha kecil atau usaha besar dengan jumlah kekayaan bersih lebih dari Rp. $500.000 .000,00$ sampai dengan Rp. 10.000.000.000,00 dengan total penjualan total Rp. 2.500.000.000,00 sampai dengan Rp. 50.000.000.000,00.

Upaya memajukan ekonomi rakyat melalui pemberdayaan UMKM dengan konsep OVOP dapat dilakukan melalui (Sumodiningrat, 2015:26):

a) Keberpihakan

b) Pemberdayaan

c) Perlindungan

d) Kemitraan

e) Peraturan pemerintah

f) Subsidi

g) Pajak

h) Inovasi

i) Subsidi bukan harga

j) Pasarglobal: pasar bebas tidak terkendali.

Ekonomi rakyat pada prinsipnya adalah ekonomi yang berasal dari rakyat, oleh rakyat dan untuk rakyat (Sumodiningrat, 2015: 5). Dalam sistem ekonomi kerakyatan, peran pemerintah diwujudkan dalam bentuk:

a) Memberikan dan membuka lapangan kerja seluas luasnya untuk setiap warga negara demi mendapat penghidupan yang layak

b) Membangun koperasi sebagai wadah semangat membangun perekonomian rakyat

c) Mengembangakan perusahaan milik Negara (BUMN) untuk kesejahteraan rakyat

d) Memlihara fakir miskin dan anak terlantar.

Penelitian tentang Pendekatan One Village One Product untuk Meningkatkan Kreatifitas UMKM dan Kesejahteraan Masyarakat yang dilakukan oleh Rusnandari menjelaskan bahwa sentra dan Produk OVOP ditentukan sesuai dengan kriteria daerah antara lain wilayah dengan potensi 
Pemberdayaan UMKM berbasis "One Village One Product" (OVOP) Sebagai Gerakan Ekonomi Kerakyatan Pada Industri Logam Desa Hadipolo Kudus

unggulan, proses produksi kontinyu, produk yang memiliki kearifan lokal, komitmen pemerintah, pengurus sentra, kesesuaian terhadap Perda, kesediaan bahan baku dan kemudahan akses. Namun dalam penerapan di industri batik Surakarta terdapat beberapa hambatan antara lain lemahnya koordinasi antar stakeholder, kurangnya kesadaran masyarakat akan potensi ekonomi di daerahnya serta kurangnya dukungan dana pemerintah pusat dan pemerintah daerah. Disatu sisi lain pengembangan OVOP di kawasan batik Surakarta cukup signifikan dengna telah terbentuknya koperasi simpan pinjam yang membantu UMKM disektor permodalan.

Sedangkan menurut penelitian yang dilakukan Triharini yang berjudul Pendekatan One Village One Product untuk mengembangkan potensi kerajinan gerabah di Kecamatan Plered Purwarkarta menyatakan bahwa hal tersebut tidak hanya memberikan manfaat secara ekonomi berupa peningkatan pendapatan keluarga pengrajin tetapi juga mampu menjaga kearifan lokal melalui nilai - nilai tradisonal yang diwariskan kepada generasi muda. Kemudian untuk aspek aspek OVOP untuk setiap cluster UMKM memiliki keunikan tersendiri yang berbeda dengan cluster UMKM lainnya. Pelaksanaan program OVOP di daerah Plered masih belum maksimal sesuai dengan prinsip yang dikembangkan. Perlu adanya dukungan dan keterlibatan seluruh stakeholder guna mendukung keberhasilannya. Beberapa yang menjadi factor penentu keberhasilan OVOP adalah tujuan, inisiator, sumber pendanaan, pelaksanaan, partisispasi, desain, pendampingan serta pemasaran.

\section{METODE PENELITIAN}

Penelitian ini adalah penelitian lapangan (field research) yaitu penelitian yang dilakukan di lapangan atau di lingkungan tertentu (Arikunto, 1998:11). Pendekatan yang dipakai adalah pendekatan deskriptif kualitatif. Objek penelitian adalah UMKM sentra industri logam yang berlokasi di Desa Hadipolo Kecamatan Jekulo Kabupaten Kudus. Data primer peneliti dapatkan melalui observasi secara langsung, wawancara mendalam dan juga Forum Group Discussion (FGD). Sumber data sekunder peneliti peroleh dari arsip, literature, dokumen, kebijkan dan artikel publikasi. Teknik analisa data dalam penelitian ini adalah adalah analisis data kualitatif, dimana analisis dilakukan sejak sebelum memasuki lapangan, selama berada di lapangan dan setelah selesai dari lapangan. Miles and Huberman (1984) mengemukakan bahwa aktifitas dalam analisis data kualitatif dilakukan secara interaktif dan berlangsung secara terus menerus sampai tuntas, sehingga datanya sudah jenuh (Sugiyono, 2005:334). Analisis Data kualitatif meliputi langkah data reduction, data display dan conclution drawing.

\section{PEMBAHASAN}

Kudus merupakan salah satu kabupaten kecil dengan berbagai potensi ekonomi yang luar biasa. Terdapat berbagi cluster industri yang berkembang salah satunya adalah cluster logam atau pande besi yang terdapat di desa 
Hadipolo. Sesuai dengan Inpres Republik Indonesia Nomor 6 tahun 2007 tentang kebijakan percepatan pengembangan sektor riil dan pemberdayaan usaha mikro kecil dan menengah yang diimplementasikan dengan peraturan menteri perindustrian Nomor 78/ M-IND/PER/9/2007 tentang peningkatan efektifitas pengembangan IKM melalui pendekatan satu desa satu produk (OVOP) Pemerintah Kabupaten Kudus melalui Dinas Tenaga Kerja, Transmigrasi, Koperasai dan UMKM sangat mendukung upaya pemberdayaan UMKM.

Selain sebagai upaya peningkatan kesejahretaaan ekonomi, pemberdayaan UMKM melalui OVOP juga akan memiliki efek domino lain salah satunya adalah mengantisipasi depopulasi usia produktif di desa. Dengan adanya UMKM yang berkembang pesat diharapkan pemuda tidak segan untuk tetap bertahan di daerahnya membangun desanya sendiri. Konsep OVOP sendiri juga mampu memberikan kepuasan batin bagi masyarakat lokal karena adanya penghargaan terhadap potensi dan kearifan lokal.

Melalui Program OVOP diharapkan UMKM mampu berdaya saing terhadap sektor - sektor usaha lain terutama perusahaan perusahaan multinasional. Keberadaan UMKM juga diharapkan mampu memperkuat struktur industri nasional, menyerap angkatan kerja yang yang signifikan serta mengurangi angka kemiskinan. Sesuai dengan prinsip dasar OVOP, yang pertama adalah local but global. Hal ini berarti desa harus mampu menghasilkan produk dengan mamnfaatkan sumber daya baik alam maupun manusia lokal tetapi memiliki kualitas dan daya saing yang bersifat global. Dalam rangka mencapai hal tersebut UMKM dituntut untuk lebih kreatif dan inovatif sehingga mampu menghasilkan produk yang only one dan number one. Prinsip OVOP yang kedua adalah self reliance and creativity yang berarti dalam pengembangan OVOP harus mendasarkan pada kemandirian, inisiatif dan kraetifitas masyarakat setempat. Prinsip human resource and development merupakan prinsip yang berarti program OVOP harus mampu mengembangkan sumber daya manusia yang ada agar lebih kreatif dan mandiri.

Konsep OVOP merupakan konsep yang terbuka dalam arti konsep ini dapat diaplikasikan dalam berbagai situasi daerah yang berbeda dengan tetap menjunjung tinggi kearifan lokal dari masing masing daerah. Dewasa ini konsep OVOP juga banyak mengalami perubahan yang lebih dinamis. Pada awalnya OVOP lebih cenderung terhadap produk yang tangible (terlihat) dalam arti barang (goods), saat ini OVOP sudah masuk pada produk yang bersifat intangible (tak terlihat) dalam arti jasa (services) seperti kebudayaan, pariwisata dan teknologi.

Sebagai sebuah program, OVOP perlu dilakukan evaluasi untuk melihat efektifitas pencapaiannya. Parameter pemberdayaan OVOP dapat dilihat dari:

1. Tujuan 
Pemberdayaan UMKM berbasis "One Village One Product" (OVOP) Sebagai Gerakan Ekonomi Kerakyatan Pada Industri Logam Desa Hadipolo Kudus

Tujuan merupakan hal yang ingin dicapai dalam pelaksanaan suatu program. Secara umum OVOP memiliki tujuan antara lain:

1) Mengoptimalkan potensi yang dimiliki desa

2) Mengurangi gap/kesenjangan ekonomi dan pembangunan antara desa dan kota

3) Mengatasi permasalahan depopulasi penduduk usia produktif di desa

4) Meningkatkan kesejahteraan ekonomi masyarakat desa

5) Memberikan nilai tambah terhadap aktivitas masyarakat yang telah dilakukan turun temurun

6) Meningkatkan bergainning position desa dan UMKM yang terdapat di dalamnya

Pengembangan OVOP di sentra pande besi Hadipolo tidak terlepas dari tujuan OVOP secara umum tersebut. Namun jika dipertajam, tujuan pengembangan OVOP di sentra pande besi Hadipolo lebih ditekankan pada untuk meningkatkan daya saing dan bargaining position produk lokal yang dihasilkan agar dapat sejajar bahkan lebih unggul dari produk luar negeri. Hal ini karena selama ini terjadi under estimate terhadap produk lokal. Padahal jika ditelusuri lebih jauh produk industri logam hasil UMKM sentra pande besi Desa Hadipolo memiliki kualitas yang tidak kalah terhadap produk asing. Hal lain juga produk lokal memiliki tingkat harga yang jauh lebih bersaing dibanding produk lainnya.

2. Inisiator

Sebuah kebijakan yang dijalankan dilapangan dapat bersifat top button atau button up, tergantung dari pihak mana inisisasi kebijakan tersebut dimulai. Kebijakan bersifat top button jika kebijakan tersebut diinisiasi oleh pemerintah, sedangkan masyarakat sebagai pelaku utama. Berbeda dengan top button, kebijakan yang bersifat button up cenderung diinisiasi oleh masyarakat sesuai dengan kondisi dan potensi yang ada di masyarakat. Peran pemerintah sebagai pendukung, pendamping dan pengarah kebijakan tersebut. Pengembangan OVOP yang dicanangkan di sentra UMKM pande besi Desa Hadipolo merupakan kombinasi diantara dua bentuk kebijakan tersebut. Selain inisiasi dari masyarakat dalam hal ini pelaku bisnis UMKM, pemerintah kabupaten Kudus melalui Dinas Tenaga Kerja Transmigrasi Koperasi dan UMKM juga menyambut positif dengan berbagai bentuk dukungan. Kesadaran pelaku UMKM setempat untuk mendukung pengembangan OVOP salah satunya adalah membentuk kelompok usaha bersama yang diberi nama Citra Usaha Logam. Melalui KUB Citra Usaha Logam, pelaku UMKM pande besi desa Hadipolo memiliki bargaining position yang lebih saat berinteraksi dengan pihak lain. Selain itu keberadaan KUB juga mampu mengurangi persaingan yang kurang sehat antar pelaku UMKM. Hal ini senada dengan pendapat Tambunan (2005) yang menyatakan bahwa salah satu strategi pengembangan UMKM yang sangat baik diterapkan di negara berkembang adalah pengelompokkan (clustering). Dengan pengelompokkan pada sub sektor usaha yang sama, kerjasama sekaligus persaiangan yang terjadi antar UMKM akan dapat meningkatkan efisiensi 
bersama (collective efficiency) dalam proses prooduksi, spesialisasi yang fleksibel (flexible specialization) dan pertumbuhan yang tinggi.

3. Pihak yang terlibat selain inisiator

Pengembangan OVOP tidak dapat dijalankan secara independen hanya oleh pelaku UMKM semata. Perlu adanya dukungan pihak lain yang telibat di dalamnya. Pada sentra Pande besi Hadipolo, pemerintah baik dari tingkat kabupaten melalui Disnakertranskop dan UMKM hingga pemerintah tingkat desa memberikan dukungan yang cukup besar melalui berbagai kebijakan yang memihak (affirmative policy). Bantuan permodalan, bantuan alat serta jaringan pemasaran melalui berbagai event kerap diberikan oleh pemerintah setempat. Akademisi dari berbagai universitas yang ada di sekitar juga banyak memberikan kontribusi seperti pelatihan dan penyuluhan baik terkait teknis produksi maupun pemasaran.

4. Sumber pendanaan

Terkait sumber pendanaan, pengembangan OVOP di sentra pande besi Hadipolo lebih banyak ditopang dari kemandirian pelaku UMKM itu sendiri. Meskipun tetap masuknya dana dari pihak lain tetap ada, salah satunya adalah pemerintah. Pemberiaan dana bantuan yang dialokasikan sama terhadap pelaku UMKM dirasa kurang tepat. Penyaluran dan nominal besarnya dana bantuan harusnya disesuaikan dengan komitmen dan dedikasi tiap tiap UMKM. Harapannya dengan sistem reward yang lebih ini dapat memotivasi UMKM untuk mengembangkan diri

5. Tahap tahap pelaksanaan

Rencana penegmbangan OVOP meliputi:

1) Koordinasi dengan stakeholder di daerah dan penyusunan rencana tindak lanjut ke depan

2) Pengenalan akses pasar melalui promosi produk dan temu bisnis baik di pasar lokal maupun internasional

3) Pendampingan baik terkait desain, teknis produksi mauppun packaging

4) Fasilitasi penguatan sarana pendukung

5) Promosi melalui pameran, publikasi maupun festival

6) Peningkatan kualitas sumber daya manusia

7) Temu bisnis dengan calon pembeli.

Pada pengembangan UMKM berbasis OVOP di sentra pande besi desa Hadipolo, tahap perencanaan dilakukan melalui temu pengrajin dan musrenbang yang tidak hanya melibbatkan pengrajin, tetapi juga pemerintah dan masyarakat sekitar. Pada tahap ini telah menghasilkan rencana aksi yang perlu diimplementasikan secara riil. Pada tahap pelaksanaan, beberapa kegiatan yang telah dilaksanakan adalah melalukan riset lapangan, penetapan produk, pendampingan teknis, pembentukan kelompok usaha bersama, perluasan pasar melalui jaringa on line, pameran dan event event nasional lainnya. Evaluasi dilakukan secara rutin dan berkesinambungan baik dari pengurus kelompok usaha bersama maupun dari disnakertranskop dan UMKM setempat. Hasil dari pantauan menjadi feedback dalam membuat dan menentukan kebijakan berikutnya. 
Pemberdayaan UMKM berbasis "One Village One Product" (OVOP) Sebagai Gerakan Ekonomi Kerakyatan Pada Industri Logam Desa Hadipolo Kudus

6. Bentuk partisipasi dalam menentukan produk

Produk yang dihasilkan oleh sentra industri logam Hadipolo pada awalnya adalah hanya beberapa perlatan rumah tangga utama berbahan dasar logam, seperti pisau, sabit, dan bendo. Namun seiring dengan pekmebngan sistem pemasaran pengrajin mulai melakukan diversifikasi dengan menghasilkan berbagai produk logam lain seperti garu, parang, cangkul, cetok dan peralatan dapur lainnya. Produk tersebut juga banyak mengalami metamorphosis dari yang awalnya sederhana menjadi lebih modern dan eksklusif. Sebagai contoh, pisau yang awalnya hanya pisau dapur saja sekarang sudah dibedakan menjadi berbagai macam pisau yang berbeda desain, bentuk dan kegunaannya. Seperti pisau daging, pisau acar, pisau buah, pisau ukir, pisau roti dan lainnya

7. Desain

Pepatah lama mengatakan "dari mata turun ke hati" yang artinya kurang lebih ketertarikan hati dimulai dari apa yang terlihat terlebih dahulu. Pepatah ini bukan hanya untuk persoalan asmara, bahkan dalam bisnis pepatah ini juga berlaku. Konsumen mengawali pilihannya terhadap suatu produk, jika produk tersebut bagus dipandang. Disinilah pelaku UMKM sebagai produsen harus menciptakan desain produk yang mampu memikat hati calon konsumen. Demikian pula yang harus dilakukan oleh pelaku UMKM pande besi di desa hadipolo.

Meskipun memproduksi barang barang olahan logam seperti pisau, sabit, garu dan perlatan rumah tangga lainnya bukan berarti pelaku UMKM berhenti berinovasi terhadap produknya. Inovasi dan kreatifitas baru wajib diperlukan agar produk mampu survive di tengah gempuran produk asing di pasaran. Di sentra pande besi Hadipolo, ide desain berasal dari pengrajin sendiri. Pengrajin tidak memiliki desainer khusus untuk produknya.

Desain yang dibuat oleh pengrajin juga biasanya mengangkat dan memperkenalkan kearifan lokal masyarakat setempat. Dalam permasalah bahan baku, bahan baku utama terdiri dari plat baja dan juga kayu.untuk plat baja sebagian besar dipasok dari pengepul barang bekas yang kebetulan juga bayak terdapat di wilayah hadipolo. Sedangkan kayu berasal dari daerah setempat. Proses produksi di pande besi masih dilakukan secara tradisional dengan melebur potongan plat baja dan biji besi kedalam tungku api. Modernisasi

8. Bentuk pendampingan

Agar mampu survive ditengah persaingan bisnis yang semakin gencar pengrajin perlu belajar dan menambah ilmu. Bagi pengusaha belajar merupakan kegiatan bisnis sepanjang hidup (long life business). Hal iini juga dialami oleh pengrajin pande besi di hadipolo. Terdapat berbagi seminar, pelatihan dan workshop yang diselenggarakan baik oleh kelompok usaha bersama, pemerintah, universitas maupun LSM lain yang diperuntukkan bagi pengrajin. Namun kesadaran untuk mengikuti berbagai pendampingan tersebut masih minim. Hanya pengrajin tertentu yang secara rutin 
mengikutinya. Sebagian besar pengrajin lainnya enggan mengikuti pendampingan tersebut dengan berbagai alasan salah satunya kesibukan kerja. Sehingga masih menjadi persoalan utama untuk mengubah mindset pengrajin agara mau lebih terbuka terhadap perubahan dan perkembangan dunia usaha melalui berbagai event.

9. Jalur pemasaran

Keberhasilan sebuah usaha tidak hanya berhenti pada aspek teknis produksi semata. Tetapi yang cukup memegang peran adalah bagaimana memasarkan produk tersebut hingga sampai ke tangan dan memberikan kepuasaan bagi konsumen. Karena kepuasan konsumen inilah yang menjadi kunci perusahaan tetap going concern di tengah persaingan bisnis. Berbagai model dan sistem pemasaran dewasa ini berkembang sangat cepat dengan dukungan perkembangan sistem informasi dan teknologi. Pemasaran tidak hanya dilakukan secara offline melalui lapak lapak di pasar saja tetapi lebih pada sistem pemasaran on line dengan jangkauan tidak hanya nasional bahkan internasional.

Meskipun demikian program rintisan OVOP yang dikembangkan di sentra industri logam Desa Hadipolo Kecamatan Jekulo Kabupaten Kudus ini, memiliki beberapa tantangan dan hambatan, antara lain:

1) Minimnya pengetahuan dari pelaku UMKM dan juga masyarakat sekitar mengenai OVOP

2) Masih sulinya membangun kesadaran akan kerjasama antarUMKM dalam rangka meningkatkan posisi tawar produk dan industrinya

3) Proses produksi masih banyak terkendala dengan terbatasnya teknologi

4) Terbatsnya jaringan pemasaran bagi sebagian pelaku UMKM

5) Perlunya komitmen dan keretlibatan seluruh komponen baik pelaku UMKM, masyarakat setempat dan juga pemerintah

\section{SIMPULAN}

1 Pelaksanaan OVOP harus menyesuaikan dengan kondisi setempat, artinya memperhatikan aspek potensi wilayah, kearifan lokal, dan aspek pembatas lainnya.

2 Hambatan dalam pengembangan adalah terbatasnya modal, tidak efektifnya lembaga pendampingan dan minimnya pengembangan SDM

3 Masih kurangnya spirit seluruh stakeholder yang terlibat untuk membangun dan mengembangkan potensi diri sendiri

4 Lemahnya koordinasi antar seluruh stakeholder

5 Tidak terdapat buku baku petunjuk teknis pengembangan OVOP sebagai rundown pelaksanaan program

\section{REKOMENDASI}

1. Pembinaan yang diberikan tidak hanya pada persoalan yang bersifat teknis semata, tetapi juga pembinaan yang bersifat non teknis bagi semua stakeholder yang terkait, terutama membangun kesadaran masyarakat setempat 
Pemberdayaan UMKM berbasis "One Village One Product" (OVOP) Sebagai Gerakan Ekonomi Kerakyatan Pada Industri Logam Desa Hadipolo Kudus

2. Program yang disusun harus disesuaikan dengan kebutuhan, baik materi maupun rentang waktu pelaksanaan dengan berorientasi pada target dan tujuan pengembangan yang bersifat dinamis.

3. Pelaksaan monitoring dan evaluasi secara berkala agar kesinambungan program dan hasil bisa dicapai

4. Membangun jaringan pemasaran yang luas baik dengan pemerintah maupun swasta

5. Perlunya membangun kesadaran akan pentingnya kemandirian untuk memajukan usaha dan daerahnya dengan mengurangi ketergantungan terhadap pemerintah 


\section{DAFTAR PUSTAKA}

Arikunto, Suharsimi. (1998). Prosedur Penelitian. Jakarta: Rineka Cipta.

Baswir, Revrisond. (2004). Drama Ekonomi Indonesia. Yogyakarta: Kreasi Wacana.

Cahyani, Rusnandari R. (2013). Pendekatan One Village One Product untuk Meningkatkan Kreativitas UMKM dan Kesejahteraan Masyarakat. JP FEB Unsoed Vol. 3(1).

Farida, Ai Siti. (2011). Sistem Ekonomi Indonesia. Bandung: Pustaka Setia.

Kementerian Perindustrian. (2007). Pedoman Umum dan Petunjuk Teknis Pengembangan IKM melalui Pendekatan Satu Desa Satu Produk (One Village One Product-OVOP). Jakarta: Dirjen IKM Kementerian Perindustrian.

Moeloeng, Lexy J. (1991). Metodologi Penelitian Kualitatif. Bandung: Remaja Rosda Karya.

Ningrum, Desi Aditya. (2018). Dikuasai produk asing, Mendag wajibkan ecommerce jual produk lokal https://www.merdeka.com/uang/dikuasaiproduk-asing-mendag-wajibkan-e-commerce-jual-produk-lokal.html

Sumodiningrat, Gunawan. (2015). Menuju Ekonomi Berdikari. Jakarta: Media Presindo.

Sugiyono. (2005). Memahami Penelitian Kualitatif. Bandung: Alfabeta.

Tambunan, Tulus T.H. (2002). Usaha Kecil dan Menengah di Indonesia: Beberapa Isu Penting. Jakarta: Penerbit Salemba Empat.

Tim Penyusun. (2008). Undang Undang Republik Indonesia No. 20 tahun 2008 tentang Usaha Mikro, Kecil, dan Menengah. Jakarta: Sekretariat Negara.

Tim Penyusun. Undang Undang Dasar 1945. Jakarta: Sekretariat Negara.

Triharini, Meirina, Dwinita Larasati, dan R. Susanto. (2012). "Pendekatan One Village One Product (OVOP) untuk Mengembangkan Potensi Kerajinan Daerah: Studi Kasus Kerajinan Gerabah di Kecamatan Plered, Kabupaten Purwakarta“. ITB J. Vis. Art \& Des, Vol. 6, (1), 28-41.

BAPPENAS. (2016). Warta UMKM Vol. 5 (1). 